Lampiran Kandungan gisi pakan (30\% rumput gajah dan $70 \%$ konsentrat)

\begin{tabular}{lrr}
\hline \hline & Kelompok I & Kelompok II \\
\hline Bahan kering, \% & 66,05 & 68,07 \\
Protein kasar, \% & 9,33 & 14,28 \\
TDN, \% & 68,24 & 68,44 \\
Serat kasar, \% & 20,62 & 19,96 \\
Lemak, \% & 5,25 & 6,59 \\
Ca, \% & 0,91 & 0,76 \\
P. \% & 0,67 & 0,93 \\
\hline
\end{tabular}

\title{
ANALISIS FINANSIIL USAHA SAPI PERAH KREDIT PADA PETANI PETERNAK DI DAERAH BOYOLALI (Studi Kasus KUD Cepogo Boyolali)
}

\author{
Rini Widiati *)
}

\section{INTI SARI}

Tujuan penelitian ini adalah untuk mengetahui kelayakan usaha secara finansiil dari pemeliharaan sapi perah impor melalui kredit KUD Cepogo, Boyolali.

Penelitian dilakukan dengan metode survai kepada peternak sapi perah sampel sebanyak 30 responden yang diambil secara purposive random sampling dari peternak yang mengambil kredit sapi perah impor periode 1988/ 1989.

Analisis kelayakan usaha secara finansiil menggunakan kriteria : (1) Benefit Cost Ratio (B/c) (2) Net Present Value (NPV), (3) Internal Rate of Return (IRR), dan (4) Breakeven point (BEP).

\footnotetext{
*) Staf Jurusan Sosial Ekonomi Fakultas Peternakan UGM.
}

Hasil analisis menunjukkan bahwa BEP produksi setara dengan 7,2 liter susu per hari, sedangkan produksi susu riil pada saat penelitian (sapi umumnya baru laktasi pertama) rata-rata telah mencapai 7.7 liter/ekor/hari. Selanjutnya $\mathrm{B} / \mathrm{c}=1,18, \mathrm{NPV}=\mathrm{Rp} 747.000,00$ dan IRR $=21,8 \%$. Berdasarkan hasil analisis finansil tersebut, usaha sapi perah impor melalui kredit KUD Cepogo telah memenuhi kriteria kelayakan untuk diusahakan.

(Kata kunci : Sapi Perah, Analisis finansiil). 


\section{ABSTRACT \\ FINANCIAL ANALXSIS OF THE FARMERS \\ CREDIT DAIRY CATTLE AT BOYOLALI \\ (Case study KUD Cepogo, Boyolali)}

The main objective of this study was to asses feasibility about financially imported dairy cattle throgh the credit of KUD Cepogo, Boyolali.

The method used was a survey method to the farmers of the imported dairy cattle as samples with 30 respondents. The respondents had been taken by purposively random sampling to the farmers which were taking the imported dairy cattle credit period of 1988/ 1989.

The analysis of feasibility used criteria of (1) Benefit Cost Ratio (B/C), (2) Net Present Value (NPV), (3) Internal Rate of Return (IRR), dan (4) Breakeven Point (BEP).

The results of analysis showed that BEP of cattle production was representing 7,2 liters of milk per day, Compared with then milk average real production had reached 7.7 litters per day. The $\mathrm{B} / \mathrm{c}$ was 1.18 , NPV was Rp $747,000,00$ and IRR was $21,8 \%$. Based on the financial analysis, the imported dairy cattle credit had been satis fied to be performed.

(Key words : Dairy Cattle, Financial Analysis)

\section{PENDAHULUAN}

Kondisi persusuan di Indonesia pada awal Pelita III sangat memprihatinkan, berdasarkan Buku Statistik Peternakan (1983), produksi susu dalam negeri pada tahun 1978 hanya $9 \%$ dari keseluruhan konsumsi susu penduduk Indonesia dan lainnya tergantung dari susu impor.

Untuk mengurangi ketergantungan susu impor, pemerintah sejak tahun 1979 , telah melakukan program impor sapi perah untuk discbarkan kepada petani peternak dengan cara kredit. Program tersebut berlanjut sampai sekarang dengan tujuan : (1) menambah populasi dan memperbaiki mutu genetik temak; meningkatkan produksi susu dalam negeri sampai $50 \%$ atau $1: 1$ dengan susu impor; (2) memberikan kesempatan kerja dan berusaha bagi masyarakat pedesaan dan (3) meningkatkan kesejahteraan petani masyarakat pedesaan dan (3) meningkatkan kesejahteraan petani peternak melalui peningkatan pendapatan (Ditjen Peternakan, 1983).

Ditinjau dari segi peningkatan produksi dengan adanya kebijaksanaan diatas, produksi susu dalam negeri telah menunjukkan peningkatan yaitu dari $9 \%$ pada tahun 1978 menjadi $20 \%$ pada tahun 1983 dan pada tahun 1988 telah mencapai $31 \%$ dari seluruh konsumsi susu penduduk Indonesia (Buku Statistik Peternakan 1983 dan 1989). Namun demikian ditinjau dari segi investasi pelaksanaan program diatas masih banyak mengalami hambatan, antara lain kemampuan petani untuk mengembalikan kredit. Hal ini terlihat dari banyaknya kasus tunggakan kredit dari penamaan modal pada sub sektor persusuan tersebut.

Ketidak kemampuan para petani mengembalikan kredit sapi perah impor antara lain disebabkan oleh beberapa masalah, baik yang tergolong masalah teknis, manajemen, sosial ekonomi dan faktor kelembagaan seperti Koperasi Unit Desa (KUD) dan Perusahaan Inti Rakyat (PIR) yang terkait dengan usaha sapi perah impor melalui kredit tersebut.

Dalam tulisan ini penulis mencoba mengevaluasi secara finansiil usaha sapi perah impor melalui kredit yang terkait dengan KUD Kecamatan Cepogo Boyolali Jawa Tengah. Dengan tulisan ini diharapkan dapat memberikan informasi untuk menyusun langkah-langkah selanjutnya kebijaksanaan di bidang persusuan.

\section{MATERI DAN METODE}

\section{Metode Analisis}

Untuk melihat kelayakan usaha sapi perah impor melalui kredit dipakai analisis finansiil dengan kriteria : (1) Benefit Cost Ratio (B/C) (2) Net Present Value (NPV) (3) Internal Rate of Return dan (4) Breakeven Point (BEP), (Gittinger, 1982 dan Siregar, 1985). Rumusan analisis tersebut adalah sebagai berikut :

$$
\begin{aligned}
& \text { 1. } B / C=\frac{\sum_{t=0}^{n} B t /(1+r)^{t}}{\sum_{t=0}^{n} C t /(1+r)^{t}} \\
& \text { 2. NPV }=\sum_{t=0}^{n} \frac{B t}{(1+r)^{t}}-\sum_{t=0} \frac{C t}{(1+r)^{t}}
\end{aligned}
$$


3. IRR $=$ pada saat $\sum_{t=0}^{\mathrm{n}} \frac{\mathrm{Bt}}{(1+\mathrm{r})^{\mathrm{t}}}=\sum_{\mathrm{t}=0}^{\mathrm{n}} \stackrel{\mathrm{Ct}}{-}$

4. $\mathrm{BEP}$ produksi $=\frac{\mathrm{FC}}{1-\frac{\mathrm{VC}}{\mathrm{P}}}$

dimana :

$\mathrm{Bt}=$ Penerimaan yang diperoleh (produksi susu, pupuk kandang dan pedet) pada tahun $\mathrm{t}$

$\mathrm{Ct}=$ Biaya pada tahun $\mathrm{t}$, termasuk biaya tctap (penyusutan, investasi dan bunga kredit) dan biaya variabel (pakan ternak, bahan bakar, obat-obatan dil).

$r$ = Tingkat bunga

$\mathrm{FC}=$ Fixed Cost (biaya tetap)

$\mathrm{VC}=$ Variabel Cost (biaya variabel)

$\mathrm{P}=$ Penjualan produksi per ekor induk sapi perah kredit.

Untuk menunjang perhitungan kriteria diatas dibuat "cash flow" dari usaha sapi perah kredit (lampiran 1).

Sumber data penelitian ini menggunakan data primer dan data sekunder. Data primer tentang teknis pemeliharaan sapi perah impor, kcefisien produksi, biaya dan penerimaan dari usaha sapi perah kredit dikumpulkan dari petani peternak sapi perah kredit yang terkait dengan KUD Kecamatan Cepogo Boyolali. Petani peternak contoh (respondeen) diambil secara purposive sampling sebanyak 30 peternak yang mengambil kredit sapi perah impor periode tahun 1988/ 1989. Pengumpulan data dilakukan dengan metode survai menggunakan kuesioner yang telah dipersiapkan sebelumnya. Sedangkan data mengenai kredit sapi perah diperoleh dari KUD dan lembaga-lembaga/instansi terkait. Pengumpulan data dilakukan pada bulan Oktober sampai dengan bulan Desember 1990.

\section{HASIL PENELITIAN DAN PEMBAHASAN}

Sebelum penulis mengutarakan hasil analisis, akan diuraikan terlebih dahulu mengenai perkembangan dan kondisi usaha sapi perah di daerah Boyolali.

Boyolali merupakan salah satu sumber produksi susu yang terbesar di wilayah Jawa Tengah. Ditinjau dari populasi sapi perah di Jawa Tengah pada tahun 1988 adalah sebesar 64000 ekor, sekitar $60 \%$ dari populasi tersebut atau 37000 ekor berasal dari Boyolali. Sapi perah impor dikembangkan di Boyolali mulai tahun 19 s/d 1982 secara kredit melalui KUD. "Dropping" sapi perah impor terhenti selama 6 tahun dan baru ada "Dropping" lagi pada tahun 1988 sampai dengan penelitian ini dilakukan.

Penelitian disini difokuskan pada analisis untuk menghitung kelayakan usaha sapi perah kredit periode "dropping" 1988/1989. Adapun komponen dan besarnya paket kredit sapi perah impor melalui KUDD Cepogo untuk "dropping" tahun 1988/1989 adalah seperti pada tabel berikut.

Tabel 1. Komponen dan nilai kredit sapi perah impor tahun 1988/1989 melalui KUD Cepogo Boyolali.

\begin{tabular}{llc}
\hline No. & Komponen & $\begin{array}{c}\text { Nilai Paket } \\
\text { (Rp) }\end{array}$ \\
\hline 1. & Satu ekor sapi perah & 1.536 .587 \\
& FH (sudah bunting \pm 5 bulan) & \\
2. & Dana Kematian & 43.500 \\
3. & Dana Pembinaan (KUD) & 12.500 \\
4. & Premi Perum PKK & 22.300 \\
\hline & Nilai paket kredit/ekor & 1.614 .887
\end{tabular}

Sumber : KUD Cepogo Boyolali

Dari tabel 1 terlihat bahwa sapi perah kredit yang diterima petemak sudah bunting, sehingga sekitar 6 bulan kemudian setelah penerimaan kredit, sapi telah berproduksi.

Meskipun satu paket kredit terdiri dari satu ekor sapi, namun demikian $56 \%$ dari peternak responden mengambil lebih dari satu paket, tetapi paling banyak hanya 3 paket.

Mengenai cara pengembalian kredit oleh peternak KUD diharuskan lunas dalam jangka waktu 7 tahun dengan tingkat bunga $12 \%$ tahun. Berdasarkan hasil penelitian maka dapat dikemukakan besarnya koefisien produksi dan biaya pemeliharaan sapi perah kredit dilokasi penelitian sebagai berikut. 
Tabel 2. Koefisien produksi sapi perah kredit (ex impor) yang dipelihara peternak responden

\begin{tabular}{ll}
\hline No. Uraian & $\begin{array}{c}\text { Sapi pada peternak } \\
\text { KUD Cepogo }\end{array}$ \\
\hline
\end{tabular}

1. Rata-rata calving interval

2. Rata-rata lama satu masa laktasi

3. Rata-rata produksi susu pada saat penelitian/hari/ekor induk

4. Estimasi produksi susu rata-rata/th *)

5. Rata-rata nilai produksi pedet + pupuk kandang/ekor induk/tahun

6. Harga susu/liter

7. Biaya pakan/ekor induk/tahun
13,9 bl

295 hari

7,7 liter

2936 liter

Rp. $147.125,00$

Rp. $\quad 315,00$

Rp. $443.805,00$

Sumber : Pengolahan data primer

*) Perhitungan sesuai dengan potensi produksi sapi perah FH berdasarkan umurnya selama masa kredit.

Berdasarkan koefisien produksi (tabel 2) dibuat estimaasi perhitungan input-output selama masa kredit 7 tahun. Dalam menghitung estimasi produksi setiap tahunnya dikonversikan berdasarkan potensi produksi sapi perah FH menurut umurnya sesuai dengan Yapp (1955).

Dari hasil perhitungan estimasi input-output kemudian dinilai uangkan dan dibuat "cash flow" dari usaha sapi perah selama masa kredit (lampiran 1).

Berdasarkan data perhitungan pada "cash flow" kemudian dihitung B/C ratio, Net Present Value (NPV) dan Internal Rate of Return (IRR) (Lampiran 2)

Sedangkan perhitungan BEP dilampirkan pada Lampiran 3.

Hasil Analisis finansiil menunjukkan bahwa :

1. BEP produksi sapi perah impor kredit melalui KUD Cepogo adalah 7,2 liter/hari/ekor atau 1840 liter/th. Produksi riil sapi perah KUD tersebut pada saat penelitian telah berada diatas produksi BEP yaitu 7,7 liter/hari.

2. NPV dari usaha sapi perah kredit KUD menunjukkan angka yang positip, yaitu Rp $747.000,00$.

3. Perhitungan $B / C$ ratio untuk sapi perah kredit KUD lebih besar dari satu $(\mathrm{B} / \mathrm{C}=1,18)$ sedangkan $\operatorname{IRR}=21,8 \%$. Apabila dibandingkan dengan tingkat bunga kredit dari bank sebesar $12 \%$ th maka IRR usaha sapi perah KUD Cepogo telah mencapai diatas tingkat bunga tersebut.

\section{KESIMPULAN}

Dilihat dari hasil perhitungan BEP, NPV, B/C ratio dan IRR yang didasarkan pada estimasi produksi dengan data pada kondisi saat ini, maka usaha sapi perah kredit KUD Kecamatan Cepogo telah memenuhi kriteria kelayakan untuk diusahakan.

Namun demikian, meskipun usaha sapi perah kredit KUD tersebut telah memenuhi kriteria kelayakan tetapi apabila dilihat dari koefisien produksinya seperti Calving Interval, lama masa laktasi dan produksi susu masih dibawah standar sapi perah ras. Oleh karena itu masih perlu terus diupayakan perbaikan koefisien produksi tersebut.

\section{DAFTAR PUSTAKA}

Anonymus, 1888. Boyolali Dalam Angka. Bapeda Pemerintah Dacrah Tingkat II Boyolali.

Direktorat Jenderal Peternakan, 1983. Buku Statistik Peternakan. Direktorat Jenderal Peternakan Departemen Pertanian, Jakarta.

Direktorat Jenderal Peternakan, 1989. Buku Statistik Peternakan, Direktorat Jendral Peternakan, Departemen Pertanian, Jakarta. 
Direktorat Jenderal Peternakan, 1983. Program Peningkatan Produksi Peternakan Dalam Repelita IV Sub Program Peningkatan Produksi Susu. Direktorat Bina Program, Ditjen Peternakan, Jakarta.

Gittinger, I.P. 1982. Economic Analysis of Agricultural Projects. VI Press Johns Hopkins, Jakarta.

Siregar, M. 1985. The Role and Finansial Analysis of Mini Coffee Processing Units. Jurnal Agro Ekonomika, $4: 40$ - 48.
Widiati, R. 1990. Penerimaan Bagian Pendapatan Usaha tani Ternak Sapi Perah Impor Yang Terkait dengan PIR dan Sistem KUD; Laporan Penelitian Proyek Pengembangan Ilmu Pengetahuan dan Teknologi No. 14/PIT/DPPM/099/1989. DP3M, Dirjen Pendidikan Tinggi, Departemen P dan K.

Yapp, V.W. anda W.B. Nevens., 1955. Dairy Cattle Selection Feeding and Management. John Wilcy and Sons. Inc., New York.

Lampiran 1. "Cash flow" usaha sapi perah impor melalui kredit KUD Cepogo - Boyolali (Rp)

\begin{tabular}{|c|c|c|c|c|c|c|c|}
\hline Uraiam & Th. I & II & III & IV & V & VI & VII \\
\hline \multicolumn{8}{|l|}{$\begin{array}{l}\text { 1. Inflow } \\
\text { a. Kredit } \\
\text { b. Penerimaan }\end{array}$} \\
\hline - Produksi susu & 517.545 & 845.145 & 950.670 & 1.056 .510 & 1.045 .800 & 1.035 .405 & 1.024 .695 \\
\hline - Pedet + pupuk & 147.125 & 147.125 & 147.125 & 147.125 & 147.125 & 147.125 & 147.125 \\
\hline $\begin{array}{l}\text { c. Saluage Value } \\
\text { dari sapi afkir }\end{array}$ & - & - & - & - & - & - & 600.000 \\
\hline Total & 2.279 .570 & 992.270 & 1.097 .795 & 1.203 .635 & 1.192 .925 & 1.182 .530 & 1.771 .820 \\
\hline
\end{tabular}

2. Out flows

\begin{tabular}{lrrrrrrr} 
a. Investasi sapi & 1.614 .900 & - & - & - & - & - & - \\
$\begin{array}{l}\text { Peralatan + kandang } \\
\text { b. Variable cost }\end{array}$ & 108.000 & - & - & - & - & - & - \\
$\begin{array}{l}\text { - pakan ternak } \\
\text { - obat-obatan }+ \\
\text { bahan bakar }\end{array}$ & 443.805 & 485.680 & 527.555 & 569.555 & 565.305 & 561.180 & 556.930 \\
& 35.081 & 35.081 & 35.081 & 35.081 & 35.081 & 35.081 & 35.081 \\
\hline Total & 2.201 .786 & 520.761 & 562.636 & 604.636 & 600.386 & 596.261 & 592.011 \\
& 77.784 & 471.509 & 535.159 & 598.999 & 592.539 & 586.269 & 1.179 .809
\end{tabular}

4. Repayment

\begin{tabular}{lrrrrrrr} 
a. Angsuran kredit & 230.700 & 230.700 & 230.700 & 230.700 & 230.700 & 230.700 & 230.700 \\
b. Pembayaran bunga & 193.786 & 166.103 & 138.419 & 110.735 & 83.051 & 55.368 & 27.684 \\
\hline Total & 424.486 & 396.803 & 369.119 & 341.435 & 313.751 & 286.086 & 258.384
\end{tabular}

5. Cumulative cash

\begin{tabular}{lrrrrrrr} 
a. Setiap tahun & $(346.702)$ & 74.706 & 166.040 & 257.564 & 278.788 & 300.201 & 921.425 \\
b. Cumulative & $(346.702)$ & $(271.081)$ & $(105.811)$ & 151.723 & 430.511 & 730.712 & 1.652 .137 \\
\hline
\end{tabular}




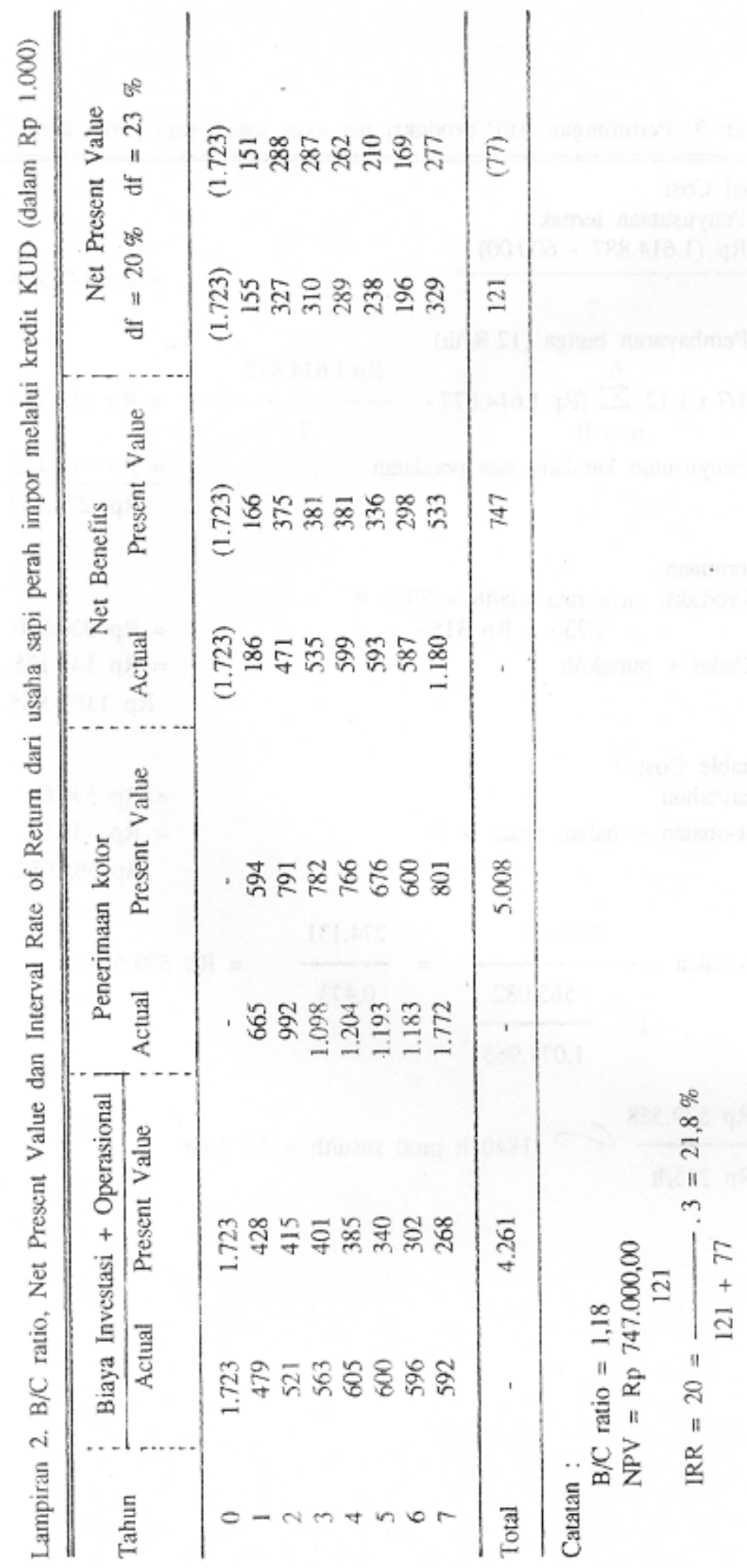


Lampiran 3. Perhitungan BEP produksi per ekor usaha sapi perah kredit KUD

1. Fixed Cost

a. Penyusutaan ternak

$R p(1.614 .887-600.00)$

7

$=\operatorname{Rp} 147.984$

b. Pembayaran bunga $(12 \% /$ th $)$
$1 / 7 \times 1,12 \sum^{6}(\operatorname{Rp~} 1.614,877$. $\mathrm{n}=0$
Rp 1.614.877 $) \quad=\operatorname{Rp~} 110.735$

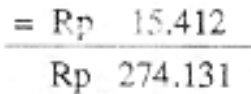
c. Penyusutan kandang dan peralatan

Rp 274.131

2. Penerimaan
a. Produksi susu rata-rata $/ \mathrm{th}=2936 \mathrm{It}$ $2936 \times$ Rp 315,-
$=\operatorname{Rp} 924.840$
b. Pedet + pupuk/th
$=\operatorname{Rp} 147.125$
$\quad \operatorname{Rp} 1.071 .965$

3. Variable Cost

Pakan/tahun

$=\operatorname{Rp} 530.001$

Obat-obatan + bahan bakar + IB

$=\operatorname{Rp} \quad 35.081$

Rp 565.082

$$
\text { BEP produksi }=\frac{274.131}{1-\frac{565.082}{1.071 .965}}=\frac{274.131}{0.473}=\operatorname{Rp} 579.558 / \mathrm{th}
$$

atau $\frac{\operatorname{Rp~} 579.558}{\operatorname{Rp} 315 / \mathrm{lt}} C 1840 \mathrm{lt}$ prod susu/th $=7,2 \mathrm{lt} / \mathrm{hr}$ 